\section{Characterization and BMP Tests of Liquid Substrates for High-rate Anaerobic Digestion}

\author{
M. Mainardis, ${ }^{\text {ab, },{ }^{*}}$ V. Cabbai, ${ }^{a}$ G. Zannier, ${ }^{\mathrm{b}}$ D. Visintini, ${ }^{a}$ and D. Goi ${ }^{\mathrm{a}}$ \\ ${ }^{a}$ Department Polytechnic of Engineering and Architecture, \\ University of Udine, Via del Cotonificio 108, 33100 Udine, Italy \\ ${ }^{b}$ CAFC S.p.A., Viale Palmanova 192, 33100 Udine, Italy
}

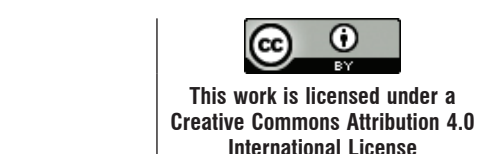

doi: 10.15255/CABEQ.2017.1083

Original scientific paper

Received: January 20, 2017

Accepted: November 14, 2017

This work was focused on the physicochemical characterization and biochemical methane potential (BMP) tests of some liquid organic substrates, to verify if they were suitable for undergoing a process of high-velocity anaerobic digestion. The selected substrates were: first and second cheese whey, organic fraction of municipal solid waste (OFMSW) leachate, condensate water and slaughterhouse liquid waste. Firstly, a physicochemical characterization was performed, using traditional and macromolecular parameters; then, batch anaerobic tests were carried out, and some continuous tests were planned.

The results revealed that all the analyzed substrates have a potential to be anaerobically treated. Valuable information about treatment rate for a high-velocity anaerobic digestion process was obtained. Start-up of a lab-scale UASB reactor, treating diluted cheese whey, was successfully achieved with good COD removal efficiency. These preliminary results are expected to be further investigated in a successive phase, where continuous tests will be conducted on condensate water and OFMSW leachate.

Key words:

BMP, anaerobic digestion, cheese whey, OFMSW leachate, slaughterhouse waste, P\&P wastewater

\section{Introduction}

Anaerobic digestion is an effective technology for improving renewable energy utilization and reducing, at the same time, GHG emissions. It can be used both for the treatment of solid and liquid substrates. Nowadays this technology is applied not only for anaerobic stabilization of sludge in WWTPs (wastewater treatment plants), but also in co-digestion processes with other organic substrates, such as OFMSW (organic fraction of municipal solid waste) or industrial wastes ${ }^{1}$.

In general, an appropriate mixture of solid or liquid matrixes helps improve $\mathrm{C} / \mathrm{N}$ ratio, macro and micro-nutrients concentration, and potential energy production ${ }^{2}$. Moreover, from a management point of view, a correct selection of valuable substrates, coming from a restricted area, maximizes resource recovery and net energy yield per unit area ${ }^{3}$.

High-velocity anaerobic treatment of wastewater, in particular UASB (up-flow anaerobic sludge blanket) technology, has raised attention in the last decades, because it allows treatment of highly polluted liquid substrates, at a reduced HRT (hydraulic retention time), if compared to traditional reactors.

"Corresponding author: E-mail address: mainardis.matia@spes.uniud.it (M. Mainardis)
In these reactors, sludge is usually present in granular form, characterized by excellent sedimentability and low SVI (sludge volume index) value, if compared with flocculent sludge. Generally, UASB treatment of highly-loaded streams produces good methane yields, reduces energy requirement (with respect to aerobic stabilization) and produces lower excess sludge ${ }^{4}$.

This work was focused on the characterization of some high-loaded liquid substrates, coming from a restricted area, specifically the mountain area of Friuli-Venezia Giulia region (Italy), in order to test their treatment potential by anaerobic process. A preliminary assay was done in order to ascertain what kind of substrates, suitable for UASB process, were available. The following matrixes were chosen and used for the experimental tests: condensate water coming from a pulp \& paper (P\&P) factory, cheese whey deriving from cheese production, slaughterhouse liquid waste and the leachate obtained from organic fraction of municipal solid waste (OFMSW) percolation.

Condensate water comes from lignin-sulphonate concentration process; it is characterized by soluble COD (sCOD) concentration in the range of 3-4 g L ${ }^{-1}$, low alkalinity and nutrients amount, scarcity of solid matter and significant sulphate and sul- 
phide concentrations. In anaerobic systems, these compounds are mainly converted to hydrogen sulphide $\left(\mathrm{H}_{2} \mathrm{~S}\right)^{5}$, which creates corrosion and odour nuisance problems.

Cheese whey is one of the residues of the cheese production chain; in particular, in daily operations, two different whey streams are produced. The first whey (whey 1) is the main sub-product of cheese production, while the second whey (whey 2) comes from a successive $100{ }^{\circ} \mathrm{C}$ cooking of the first whey, the final product of which is cottage cheese ${ }^{6}$. An approximate mass balance on dairy production shows that, for $100 \mathrm{~kg}$ of milk, $90 \mathrm{~kg}$ of whey are produced, so only $10 \mathrm{~kg}$ are transformed into cheese $^{7}$ : in fact, even in small dairy plants a lot of whey is produced, which has to be properly managed to avoid negative impacts on the environment. A direct discharge of this stream can lead to severe problems in conventional WWTPs, and also accelerate fouling phenomena in MBRs (membrane bioreactors) because of its consistent protein content ${ }^{8}$. The anaerobic process can often be a best practice to treat this liquid waste, especially when valorisation technologies, such as protein and lactose recovery, or utilization for animal feeding, are not feasible ${ }^{9}$.

OFMSW is a solid organic substrate coming from source separation of municipal solid waste. It is often used in co-digestion processes with WWTP excess sludge in order to improve methane production and reduce concentration of undesirable compounds frequently present in the sludge ${ }^{1}$. In literature a new system has been proposed, which consists of a leach bed reactor (LBR), coupled with a UASB reactor; LBR allows to extract a liquid substrate, highly soluble and readily biodegradable, suitable to undergo a high-velocity anaerobic process ${ }^{10}$. The coupling of a solid-treating LBR and a liquid-treating UASB has been named HASL (hybrid anaerobic solid-liquid reactor) and can be considered as a two-stage digestion ${ }^{11}$. This configuration allows achieving not only material recovery through composting of the solid waste, but also energy recovery through biogas generation from anaerobic treatment of leachate.

Slaughterhouse liquid waste originates from meat production; it mainly contains blood and other liquid waste coming from slaughter operations. It is a highly concentrated organic stream, and many sanitary protocols have to be taken into account during its treatment and disposal. In literature, it has been reported that the high refractory material content of this waste slows down the anaerobic digestion process ${ }^{12}$. Slaughterhouse facilities in the North Friuli area generally transport this waste out of the region, where it is finally disposed with high management costs, especially for small plants.
Substrates anaerobic biodegradability was evaluated using BMP (biochemical methane potential) test, that is a useful tool for establishing methane production potential of solid and liquid substrates, both in mono-digestion and co-digestion ${ }^{13}$. BMP tests are influenced by inoculum characteristics (origin, concentration, activity), experimental conditions (gas measurement system, operational parameters, chemical parameters, inoculum to substrate ratio) and, in scientific literature, a lack of uniformity emerges in reported data ${ }^{14}$. Moreover, when dealing with granular sludge, it was underlined that the size of the granules significantly influences biogas production ${ }^{15}$.

AMPTS (automatic methane production test system) apparatus was used for the tests; on laboratory scale and in batch mode this equipment is useful for simulation of the anaerobic digestion process, giving useful indications about total methane yield and methane production rate from selected substrates. From AMPTS, also the methane flux produced within the first 24-hours of digestion can be evaluated; in this time, the readily degradable substrate is expected to be quickly transformed to biogas, thus the first information about potential application of high-velocity UASB anaerobic treatment can be obtained.

\section{Materials and methods}

\section{Inoculum and substrates}

Granular sludge, used as inoculum in BMP and continuous tests, was obtained from a full-scale BIOPAQ ${ }^{\circledR}$ UASB bioreactor, located in Tolmezzo WWTP (northeast part of Italy).

Whey samples were collected from local dairies; first and second whey were separately collected and analysed, in order to underline the differences between these two matrixes. Two dairies in the region were selected in order to obtain a constant type of whey, taking in account its variability throughout the year. Slaughterhouse liquid waste was collected from a single slaughterhouse in the district, while condensate water was obtained from Tolmezzo P\&P factory.

OFMSW was collected from a canteen, manually selected to remove non-biodegradable materials, such as plastics or bones, and treated in the percolation bed without delay. In this work, the percolation bed was used only as a pre-treatment of the waste, to separate leachate from residual solid waste (as described by ${ }^{16}$ ); no inoculum was added to the leaching bed, differently from ${ }^{17}$ and $^{18}$.

A defined protocol was adopted, in order to make the tests reproducible; in particular, $1.4 \mathrm{~kg}$ of 
selected OFMSW were put into the percolation bed, adding $1.5 \mathrm{~L}$ of liquid. After 24 hours, the leachate was extracted and another $1.5 \mathrm{~L}$ of liquid was introduced in the percolation bed. The leachate was then extracted after another 24 hours, and the 48-hour mixture of the first and second day leachate was used for laboratory analysis and BMP tests. Globally, waste-to-water ratio was 2.1 .

Three different granulometries of OFMSW were tested: untreated waste, ground waste (diameter of waste of $12 \mathrm{~mm}$ ) and pulp waste (particle size less than $0.5 \mathrm{~mm}$ ).

\section{Analytical methods}

Liquid wastes characterization was performed according to Standard Methods for Examination of Water and Wastewater ${ }^{19}$; the analysed parameters were: total COD (tCOD), total Kjeldahl nitrogen (TKN), total solids (TS), volatile solids (VS), $\mathrm{NH}_{3}-\mathrm{N}$, alkalinity, $\mathrm{PO}_{4}^{3-}-\mathrm{P}, \mathrm{SO}_{4}^{2-}$. For the measure of $\mathrm{NH}_{3}-\mathrm{N}$, alkalinity, $\mathrm{PO}_{4}^{3-}-\mathrm{P}, \mathrm{SO}_{4}^{2-}$, the samples were centrifuged (10 minutes at $10000 \mathrm{rpm})$ before analysis.

Soluble COD (sCOD) analysis was carried out after passing samples through $0.45 \mu \mathrm{m}$ cellulose filter. Carbohydrates were analysed using Dubois method $^{20}$ with glucose as standard. Lipids were measured by gravimetric analysis after acetone hexane extraction. Volatile fatty acids (VFAs) concentration was determined by gas-chromatography with mass spectrometer (Agilent 6890 Plus/5973N) equipped with capillary column (Agilent HP-5MS).

Elemental analysis $(\mathrm{C}, \mathrm{H}, \mathrm{N}, \mathrm{S})$ was performed for dried samples (at $108{ }^{\circ} \mathrm{C}$, overnight) on an elemental analyser (Flash EA1112, ThermoQuest/CE Elantech, Lakewood, NJ) (as previously done by ${ }^{21}$ ). It was conducted using automated combustion/reduction at $900{ }^{\circ} \mathrm{C}$, followed by molecular sieve gas chromatography at $60{ }^{\circ} \mathrm{C}$ and thermal conductivity detection system.

Proteins concentration was calculated from $\mathrm{TKN}$ and $\mathrm{NH}_{3}-\mathrm{N}$ concentration; nitrogen to protein conversion factor was approximated for all substrates to 6.25 , except from cheese whey, where a value of 6.38 was used ${ }^{22}$.

\section{BMP tests}

Based on literature recommendations, a I/S (Inoculum to Substrate) ratio of 2 (on VS) was adopt$\mathrm{ed}^{23}$ in order to provide sufficient biomass to avoid inhibitory effects; for condensate water, which had no appreciable solid matter, I/S ratio was based on tCOD and set at 0.52 .

Thermostatic bath temperature was set at $35^{\circ} \mathrm{C}$ and a discontinuous (30 seconds on-30 seconds off) mixing regime was set up. Before starting the tests, every reactor was flushed with nitrogen for $30 \mathrm{sec}-$ onds to establish full anaerobic conditions ${ }^{24}$.

BMP tests were stopped when no methane production was observed for more than 24 hours. All the tests were done in triplicate with a blank control. Final BMP value was calculated by subtracting methane production of the sludge alone, from methane production of the sample, and correcting methane production of the sludge with the actual amount of biomass in the sample bottles.

All BMP tests were performed in triplicate; no $\mathrm{pH}$ correction or nutrients addition were performed, in order to analyse biomass adaptation to the substrates.

AMPTS equipment consisted of 15 individual reactors of $500 \mathrm{~mL}$ volume, each equipped with a stirrer and connected to a motor controller; the produced biogas is sent to an acid-fixation unit, that is a basic solution of soda, provided with a $\mathrm{pH}$-indicator (tymolphtalein), that indicates solution saturation. Finally, the residual biogas (essentially pure methane) arrives at the methane registration unit, formed by 15 injection mould flow cells, containing metal pieces, that open up and register every $10 \mathrm{~mL}$ volume of $\mathrm{CH}_{4}$.

\section{Continuous tests}

A lab-scale UASB reactor (11.5 L of volume) was used for some preliminary continuous tests to analyse biomass adaptation to a complex substrate, such as cheese whey, for a period of 24 days. A thermostatic bath with a water heating coil was used to heat the reactor at the proper temperature $\left(37^{\circ} \mathrm{C}\right)$.

Flow rate was fixed to obtain a constant HRT of $30.2 \mathrm{~h}$. Analysis of influent and effluent tCOD concentration, as well as $\mathrm{pH}$ monitoring were conducted daily. The $\mathrm{pH}$ correction (at 6.7-7.0) was performed daily using a $2 \mathrm{M}$ soda solution.

A mixture of the first and second whey, in the same proportions, was used as feeding substrate. The whey was diluted with tap water $(1: 50 \mathrm{v} / \mathrm{v})$ in order to reach a mean OLR of $0.88 \mathrm{~kg} \mathrm{COD} \mathrm{m}^{-3} \mathrm{~d}^{-1}$, consistent with other literature studies on start-up of anaerobic reactors treating dairy products, such as that reported by ${ }^{25}$, where a starting OLR of 0.98

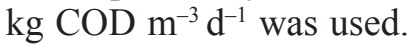

\section{Results and discussion}

\section{Substrate characterization}

The results from selected substrates characterization are summarized in Table 1. 
Table 1 -Results of the physicochemical characterization of selected substrates (expressed as mean values; STD $<10 \%$ )

\begin{tabular}{|c|c|c|c|c|c|c|c|c|}
\hline Parameter $^{\mathrm{a}}$ & $\begin{array}{l}\text { UASB } \\
\text { sludge }\end{array}$ & $\begin{array}{l}\text { Condensate } \\
\text { water }\end{array}$ & Whey 1 & Whey 2 & $\begin{array}{l}\text { Untreated } \\
\text { OFMSW }\end{array}$ & $\begin{array}{l}\text { Ground } \\
\text { OFMSW }\end{array}$ & $\begin{array}{l}\text { Pulp } \\
\text { OFMSW }\end{array}$ & Slaughter \\
\hline tCOD & n.d. ${ }^{b}$ & 4.15 & 105.0 & 81.8 & 17.9 & 40.0 & 26.5 & n.d. ${ }^{b}$ \\
\hline sCOD & 1.73 & 4.15 & 68.6 & 62.5 & 15.1 & 37.4 & 22.2 & 109.8 \\
\hline Alkalinity & 1873 & $<5$ & 1297 & 1153 & 490 & 443 & 538 & 11100 \\
\hline $\mathrm{NH}_{3}-\mathrm{N}$ & 179 & $<1$ & 44.1 & 3.19 & 24.8 & 36.5 & 41.6 & 19.6 \\
\hline TKN & 216 & 80 & 332 & 28 & 241 & 405 & 291 & 2160 \\
\hline $\mathrm{PO}_{4}^{3-}-\mathrm{P}$ & 30.8 & 0.05 & 530 & 527 & 67 & 86 & 51 & 173 \\
\hline $\mathrm{SO}_{4}^{2-}$ & $<2$ & 17.3 & $<2$ & 55.5 & 16.6 & 20.2 & $<2$ & $<2$ \\
\hline $\mathrm{pH}$ & 6.9 & 3.5 & 5.5 & 5.8 & 5.2 & 4.6 & 4.9 & 7.2 \\
\hline TS & 4.18 & 0.018 & 7.44 & 6.63 & 1.41 & 3.23 & 2.22 & 15.11 \\
\hline VS & 3.79 & n.d. ${ }^{b}$ & 6.73 & 5.64 & 0.94 & 2.57 & 1.53 & 14.29 \\
\hline VS/TS & 90.59 & n.d. ${ }^{b}$ & 90.37 & 85.18 & 66.99 & 79.52 & 68.91 & 94.57 \\
\hline VFA & 110 & 38 & 41 & 1 & 109 & 56 & 158 & 820 \\
\hline
\end{tabular}

${ }^{a} \mathrm{COD}$ expressed as $\mathrm{g} \mathrm{L}^{-1}$; Alkalinity as $\mathrm{mg} \mathrm{CaCO}_{3} \mathrm{~L}^{-1} ; \mathrm{NH}_{3}-\mathrm{N}$ as $\mathrm{mg} \mathrm{N} \mathrm{L}^{-1} ; \mathrm{PO}_{4}^{3-}-\mathrm{P}$ as $\mathrm{mg} \mathrm{P} \mathrm{L} \mathrm{P}^{-1} ; \mathrm{SO}_{4}^{2-}$, VFA and TKN as mg L ${ }^{-1}$; TS and VS as \% w/w; VS/TS as \%

${ }^{\mathrm{b}}$ n.d. $=$ not determined

It was noted that tCOD was highly variable: condensate water had the lowest value $\left(4.15 \mathrm{~g} \mathrm{~L}^{-1}\right)$, OFMSW leachate ranged from 17.9 to $40.0 \mathrm{~g} \mathrm{~L}^{-1}$, cheese whey from 81.8 to $105.0 \mathrm{~g} \mathrm{~L}^{-1}$. Ground waste leachate revealed the highest tCOD among the three OFMSW leachates. Slaughterhouse waste tCOD was not determined, because of its extremely high solids concentration.

The sCOD in condensate water was the same as tCOD (4.15 $\left.\mathrm{g} \mathrm{L}^{-1}\right)$, while in leachate, the sCOD was in the range of $15.1-37.4 \mathrm{~g} \mathrm{~L}^{-1}$. The sCOD was similar in the first and second whey (whey $1=68.6$ $\mathrm{g} \mathrm{L}^{-1}$, whey $2=62.5 \mathrm{~g} \mathrm{~L}^{-1}$ ); this led to the consideration that particulate fraction was larger in whey 1 , giving a very high tCOD. Finally, the sCOD in slaughterhouse waste, $109.8 \mathrm{~g} \mathrm{~L}^{-1}$, was even higher than literature values (for example, a range of 27.1$100.9 \mathrm{~g} \mathrm{~L}^{-1}$ was reported $\mathrm{in}^{26}$ ).

Alkalinity is a crucial parameter in anaerobic digestion process, because it helps prevent $\mathrm{pH}$ drop, which can lead to reactor failure, by inhibiting methanogenic archaea ${ }^{27}$. Alkalinity was totally absent in condensate water $\left(<5 \mathrm{mg} \mathrm{CaCO}_{3} \mathrm{~L}^{-1}\right)$, while it was low in OFMSW leachate (443-538 $\left.\mathrm{mg} \mathrm{CaCO}_{3} \mathrm{~L}^{-1}\right)$, appreciable in cheese whey $(1153-$ $1297 \mathrm{mg} \mathrm{CaCO}_{3} \mathrm{~L}^{-1}$ ), and very high in slaughterhouse waste (11100 $\left.\mathrm{mg} \mathrm{CaCO}_{3} \mathrm{~L}^{-1}\right)$.

$\mathrm{NH}_{3}$ is another key parameter, because at high concentrations, it is considered the main anaerobic process inhibitor ${ }^{5}$; the results showed that $\mathrm{NH}_{3}$ concentrations were low in all selected substrates $(<50$ $\mathrm{mg} \mathrm{N} \mathrm{L}{ }^{-1}$ ), well below the inhibitory level.
The TKN content represents the total amount of nitrogen compounds: as expected, condensate water showed the lowest TKN concentration (80 $\mathrm{mg} \mathrm{L}^{-1}$ ). The TKN concentration in OFMSW leachate was in the range of $241-405 \mathrm{mg} \mathrm{L}^{-1}$. A main difference in TKN concentration was evident between whey $1\left(332 \mathrm{mg} \mathrm{L}^{-1}\right)$ and whey $2\left(28 \mathrm{mg} \mathrm{L}^{-1}\right)$; according to this low $\mathrm{N}$ content, sometimes the second whey was also called deproteinised whey ${ }^{6}$. In slaughterhouse waste, the TKN reached values greater by one order of magnitude than that in all the other substrates $\left(2160 \mathrm{mg} \mathrm{L}^{-1}\right)$. It must be reminded that nitrogen, at low concentrations, is a necessary nutrient for the anaerobic process ${ }^{28}$.

As for $\mathrm{PO}_{4}^{3-}$-P, significant differences were observed between the various substrates: in condensate water, phosphates were practically absent $(0.05$

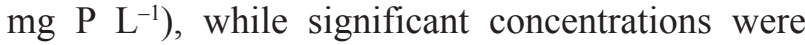
found both in slaughterhouse waste $\left(173 \mathrm{mg} \mathrm{P} \mathrm{L}^{-1}\right)$ and cheese whey (527-530 $\left.\mathrm{mg} \mathrm{P} \mathrm{L}^{-1}\right)$. In OFMSW leachate, phosphates were present in the range of 51-86 mg P L ${ }^{-1}$. Phosphorous, similarly to nitrogen, is an essential nutrient for biological metabolism; for this reason, a balanced presence of this element is a good factor for every anaerobic process ${ }^{28}$.

The $\mathrm{SO}_{4}{ }^{2-}$ concentration needs to be accurately monitored in anaerobic operations, because it is converted to $\mathrm{H}_{2} \mathrm{~S}$, which creates nuisance problems ${ }^{29}$. As for the selected substrates, $\mathrm{SO}_{4}^{2-}$ was present both in condensate water $\left(17.3 \mathrm{mg} \mathrm{L}^{-1}\right)$ and in whey $2\left(55.5 \mathrm{mg} \mathrm{L}^{-1}\right)$. The $\mathrm{SO}_{4}{ }^{2-}$ concentration in whey 1 and in slaughterhouse liquid waste was below the detection limit $\left(<2 \mathrm{mg} \mathrm{L}^{-1}\right)$. 
The $\mathrm{pH}$ is the main operational parameter that needs to be carefully controlled in continuous operations: it is well known that an increase in VFA concentration is due to process imbalance, that is acidogenesis faster than methanogenesis. This gives an additional $\mathrm{pH}$ decrease and further inhibitory effects ${ }^{30}$. All the analysed substrates had an acidic $\mathrm{pH}$, except from slaughterhouse waste, whose $\mathrm{pH}$ was 7.2; however, $\mathrm{pH}$ slightly increased from condensate water (3.5) to OFMSW leachate (4.6-5.2), to cheese whey (5.5-5.8). According to these results, the analysed cheese whey could be defined as "sweet"7.

TS and VS define the amount of solid matter in the system: these parameters are particularly important for high-rate anaerobic reactors (such as UASB), because they are not appropriate for the treatment of substrates having high solid content. In fact, solid matter, as well as floating fats, typically accumulate in the reactor blanket and are not efficiently biodegraded by granular biomass, because hydrolysis requires long retention times ${ }^{31}$. Slaughterhouse liquid waste had a significant TS content $(15.11 \% \mathrm{w} / \mathrm{w})$ that did not match with high-rate anaerobic reactor processes; TS content decreased in cheese whey $(6.63-7.44 \% \mathrm{w} / \mathrm{w})$ and mainly in OFMSW leachate $(1.41-3.23 \% \mathrm{w} / \mathrm{w})$. Condensate water had no appreciable TS content $(0.018 \%$ $\mathrm{w} / \mathrm{w})$.

VS/TS ratio shows the relative amount of volatile organic matter, which was fairly high for all selected substrates: OFMSW leachate had the minimum ratio (66.99-79.52\%), while the maximum ratio was achieved in slaughterhouse liquid waste $(94.57 \%)$

The VFA concentration is important in anaerobic process management, because fatty acids are key intermediates, which are produced by acidogenic bacteria and are successively converted to acetic acid, $\mathrm{CH}_{4}$ and $\mathrm{CO}_{2}$. The VFA concentration was low in condensate water $\left(38 \mathrm{mg} \mathrm{L}^{-1}\right)$ and in cheese whey (1-41 $\left.\mathrm{mg} \mathrm{L}^{-1}\right)$, while it was moderate in OFMSW leachate $\left(56-158 \mathrm{mg} \mathrm{L}^{-1}\right)$, and high in slaughterhouse liquid waste $\left(820 \mathrm{mg} \mathrm{L}^{-1}\right)$.

As for the physicochemical characterization, it could be noticed that the results obtained on dairy whey were consistent with other literature studies $^{6,9,32}$, even though a high variability in whey composition emerged, in particular in COD (50-102 $\left.\mathrm{g} \mathrm{L}^{-1}\right)$ and $\mathrm{pH}(3.8-6.5)^{6} . \mathrm{In}^{33}$, an acidic $\mathrm{pH}(3.44-3.92)$ was reported in whey, together with a lower COD concentration (55.3-74.5 $\mathrm{g} \mathrm{L}^{-1}$ ) than that of the present work; also $\mathrm{PO}_{4}^{3-}$ concentration was lower (124 $\mathrm{mg} \mathrm{L}^{-1}$ ).

As for OFMSW leachate, in $^{16}$ ground waste was used for percolation, and different waste-to-water ratios were tested $(1: 1,1: 2,1: 3)$. The results showed that, after 30 min contact between water and organic waste, no further solubilisation occurred; in addition, water extracts highlighted a high VS/TS ratio (83.4-88.9\%), higher than that reported in the present work. This could be explained with a worse retention of inorganic sand particles in leach bed, that could be partly dragged with the leachate.

\section{Macromolecular analysis}

Carbohydrates are readily biodegradable in anaerobic systems, while lipids, which are able to produce higher methane yields, are slowly degraded and often accumulate in the reactor, leading to operational problems, such as sludge floatation and foam formation ${ }^{27}$. Proteins are degraded to amino acids that subsequently form $\mathrm{NH}_{3}$; as a result, an excessive protein concentration can cause inhibitory effects ${ }^{5}$.

The results from macromolecular analysis are plotted in Fig. 1. UASB sludge alone was rich in greases $\left(4.545 \mathrm{~g} \mathrm{~L}^{-1}\right)$ and had a poor carbohydrate and protein concentration $\left(0.310\right.$ and $0.233 \mathrm{~g} \mathrm{~L}^{-1}$, respectively).

Condensate water had a low macromolecular content if compared to the other substrates: in particular, carbohydrate $\left(0.770 \mathrm{~g} \mathrm{~L}^{-1}\right)$ and lipid $(0.118$ $\mathrm{g} \mathrm{L}^{-1}$ ) concentrations were the lowest among the various matrixes.

A main difference between the first and second whey could be highlighted, namely whey 2 had a consistently lower lipid concentration than whey 1 (2.388 $\mathrm{g} \mathrm{L}^{-1}$ versus $32.955 \mathrm{~g} \mathrm{~L}^{-1}$ ). Whey 2 had the

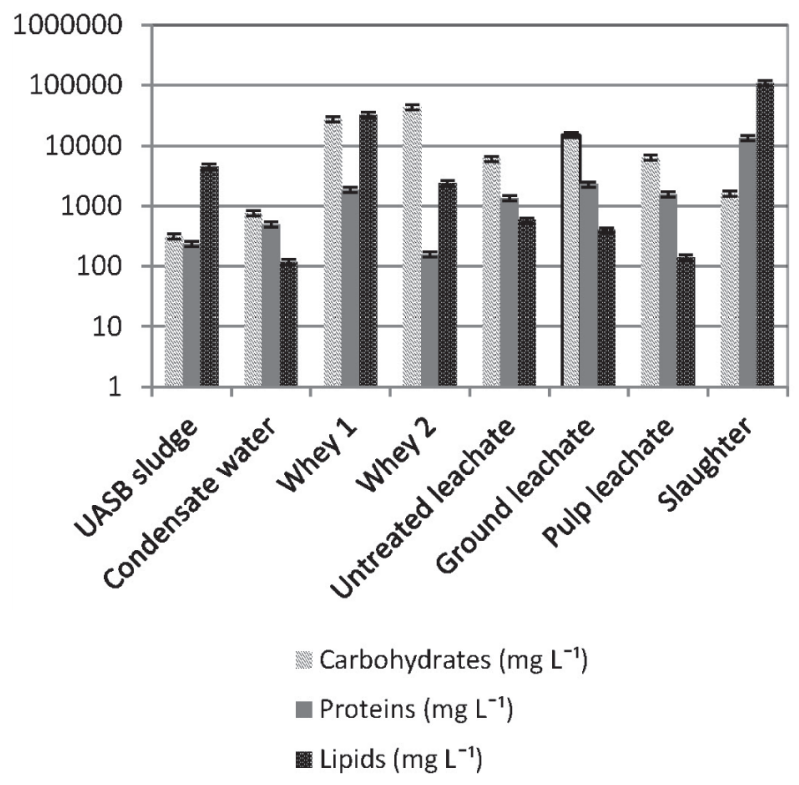

Fig. 1 - Results from macromolecular analysis of selected substrates, expressed as mean values 
lowest protein concentration $\left(0.158 \mathrm{~g} \mathrm{~L}^{-1}\right)$ and the highest carbohydrate concentration $\left(43.8 \mathrm{~g} \mathrm{~L}^{-1}\right)$ among the matrixes, so it could be considered a readily biodegradable substrate.

OFMSW leachate had a high carbohydrate concentration (6.1-15.2 $\mathrm{g} \mathrm{L}^{-1}$ ) and the obtained data demonstrated that the material size in the leaching bed did not greatly influence the macromolecular composition of the extracted liquid. Ground waste leachate had both the highest tCOD concentration $\left(40.0 \mathrm{~g} \mathrm{~L}^{-1}\right)$ and the highest carbohydrate and lipid concentrations (15.2 and $2.303 \mathrm{~g} \mathrm{~L}^{-1}$ respectively).

Finally, slaughterhouse liquid waste was rich in lipids $\left(110.25 \mathrm{~g} \mathrm{~L}^{-1}\right)$, but, as expected, it had also the highest protein concentration among the selected substrates (13.378 $\left.\mathrm{g} \mathrm{L}^{-1}\right)$.

A comparison between literature works and actual results can be fruitful: as for cheese whey, $\mathrm{in}^{9} \mathrm{a}$ lower lipid concentration $\left(0.4-5.7 \mathrm{~g} \mathrm{~L}^{-1}\right)$ was reported, together with a higher protein concentration (2.3-33.5 $\left.\mathrm{g} \mathrm{L}^{-1}\right)$, further underlining that cheese whey composition and properties greatly depend on the characteristics of raw milk and the particular cheese factories processes.

\section{Elemental analysis}

The results from elemental analysis are shown in Fig. 2.

UASB sludge was rich in $\mathrm{N}(7.1 \%)$ and also in $\mathrm{S}(9.7 \%)$; condensate water, coming from a $\mathrm{P} \& \mathrm{P}$ process, revealed in its scarce solid part an extremely high sulphur content $(12.1 \%)$ and also the lowest $\mathrm{N}$ concentration $(0.5 \%)$ among the tested substrates. Obviously, only little differences in elemental analysis were observable between the three leachates. Dairy whey was characterized by low N percentage (1.0-2.4\%); slaughterhouse liquid waste contained a high $\mathrm{C}$ content $(49.8 \%)$ and, predictably, the highest $\mathrm{N}$ level (14.6\%).

\section{BMP tests}

In Fig. 3, cumulative methane yields from BMP tests are plotted; also 24-hour methane production was analysed, because it gave useful information on processes with typical high-velocity anaerobic reactors retention time.

Condensate water tests underlined a poor methane production in the 24-h basis, due to the substrate acidity that required an acclimation period, and to nutrients scarcity. However, final BMP value from this substrate reached an interesting value of 147.5 $\mathrm{L} \mathrm{CH}_{4} \mathrm{~kg}^{-1} \mathrm{COD}_{\text {added }}$.

Cheese whey biomethanisation assays showed a poor methane production (final BMP of 22.8-36.3 $\mathrm{L} \mathrm{CH}_{4} \mathrm{~kg}^{-1} \mathrm{COD}_{\text {added }}$ ) if compared to other results reported in literature, such as that by ${ }^{33}$; as can be seen in Fig. 3, methane generation stopped just after two days of digestion. It was noted that $\mathrm{pH}$ suddenly dropped to 4.0 in the first days of digestion: because of the sudden acidification, methanogenic bacteria inhibition occurred and methane generation was interrupted. This information, coming from batch tests, suggested that $\mathrm{pH}$ correction is needed in continuous operations, to prevent process inhibition; moreover, because of the extreme COD concentration of whey, a useful dilution should be planned in order to reach an optimal influent concentration in the range of 5-10 $\mathrm{g} \mathrm{COD} \mathrm{L}^{-1}$.

BMP results from OFMSW leachate showed a moderate 24-hour methane production (30.0-44.3 $\mathrm{L} \mathrm{CH}_{4} \mathrm{~kg}^{-1} \mathrm{COD}_{\text {added }}$ ) and a good BMP value of 218.9-221.8 $\mathrm{L} \mathrm{CH}_{4} \mathrm{~kg}^{-1} \mathrm{COD}_{\text {added }}$. The difference in methane production from the three leachates was negligible.

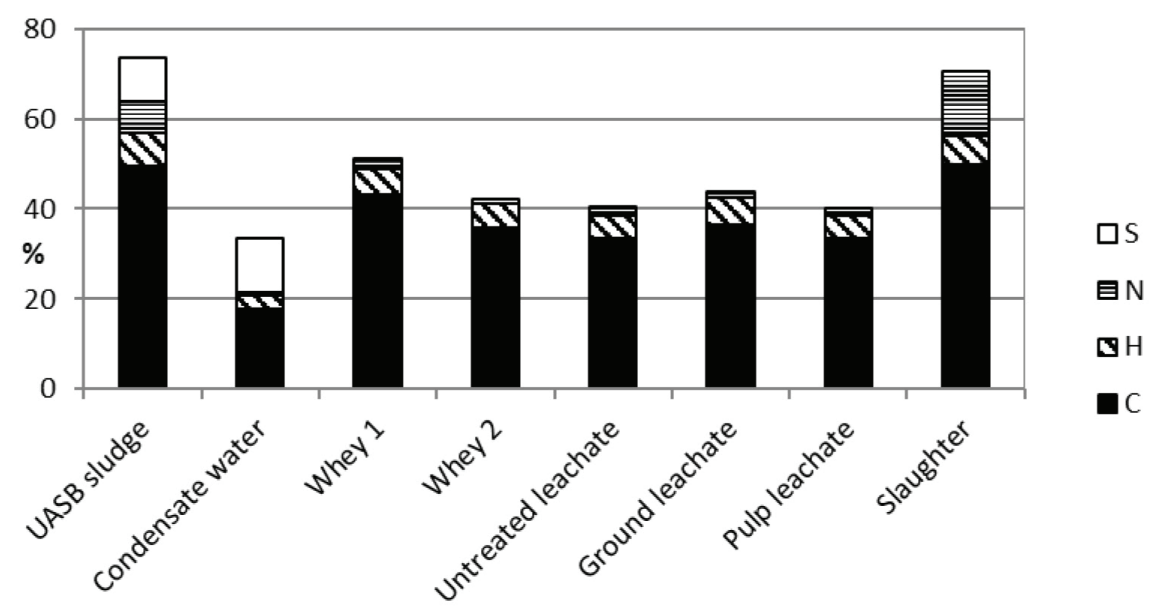

Fig. 2 - Results from elemental analysis of selected substrates, expressed as mean value 


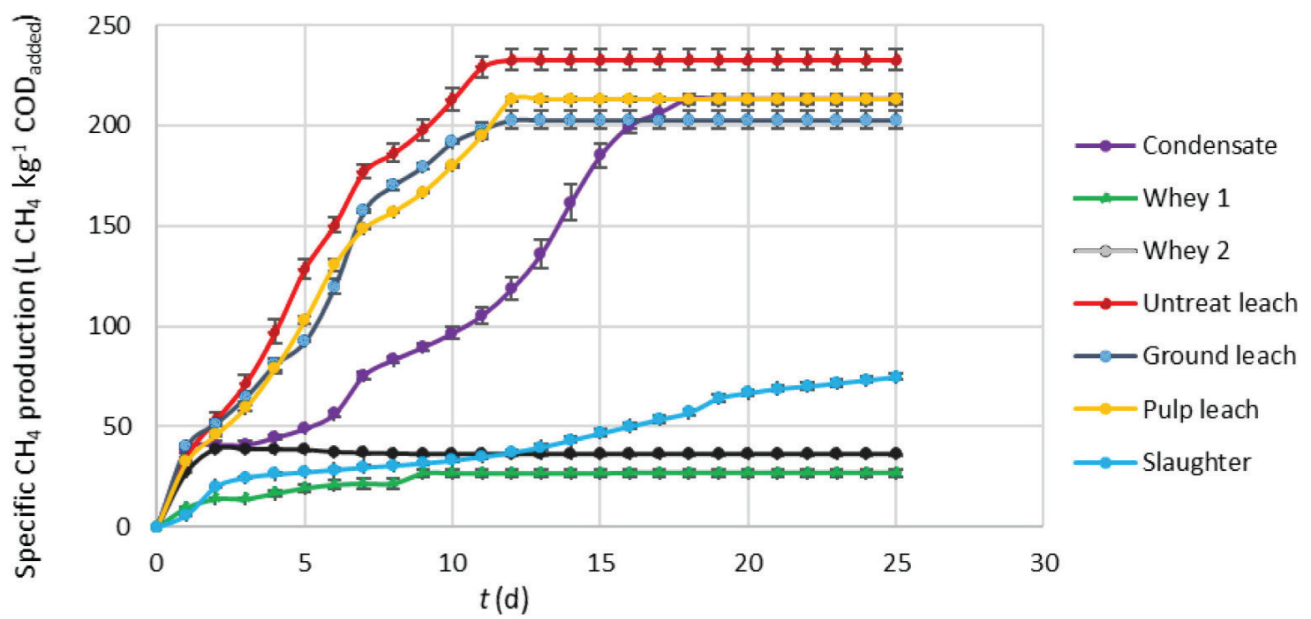

Fig. 3 - Specific methane production from BMP tests of selected substrates

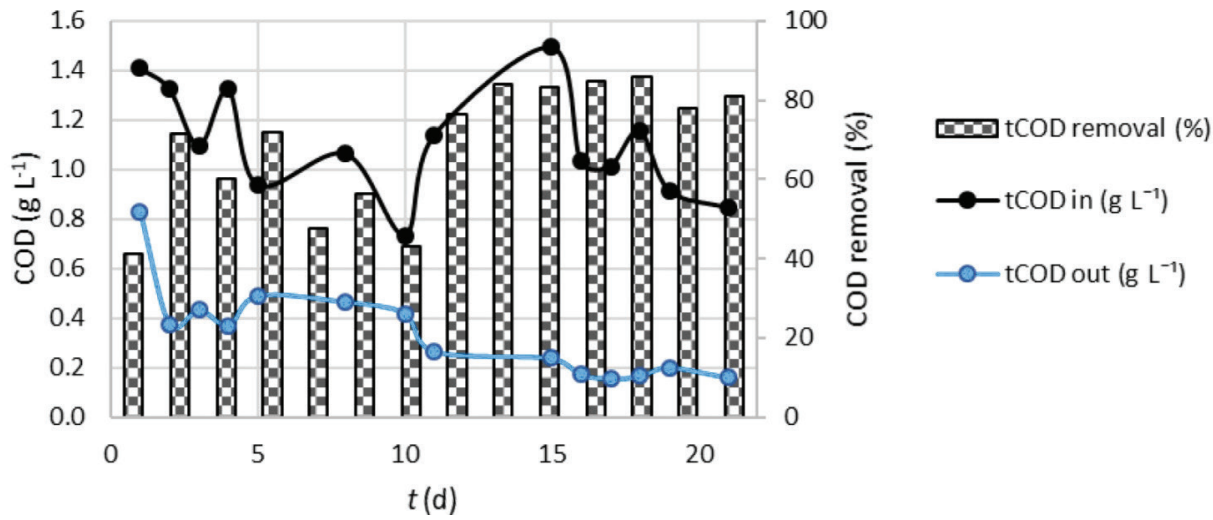

Fig. 4 - Influent and effluent tCOD concentration and COD removal from lab-UASB tests on cheese whey

On the other hand, in slaughterhouse waste digestion, methane production was very low in the 24-hour basis (4.5 $\mathrm{L} \mathrm{CH}_{4} \mathrm{~kg}^{-1} \mathrm{COD}_{\text {added }}$ ), probably because of the low adaptability of granular biomass to this substrate; successively, methane generation increased, up to the end of the tests (final BMP of $74.8 \mathrm{~L} \mathrm{CH}_{4} \mathrm{~kg}^{-1} \mathrm{COD}_{\text {added }}$ ).

For the selected matrixes, the specific maximum methane production rate and the corresponding digestion time are summarized in Table 2. It

Table 2 -Maximum specific methane production rate (expressed as $\mathrm{NmL} \mathrm{CH}_{4} h^{-1} \mathrm{~g}^{-1} \mathrm{COD}_{\text {added }}$ ) and corresponding digestion time (in h) of selected substrates

\begin{tabular}{l|c|c}
\hline \multicolumn{1}{c|}{ Substrate } & $\begin{array}{c}\text { Digestion time } \\
\text { of the peak (h) }\end{array}$ & $\begin{array}{c}\text { Maximum specific } \\
\mathrm{CH}_{4} \text { production rate } \\
\left(\mathrm{NmL} \mathrm{h}^{-1} \mathrm{~g}^{-1} \mathrm{COD}_{\text {added }}\right)\end{array}$ \\
\hline Condensate water & 1 & 15.41 \\
Whey 1 & 4 & 2.60 \\
Whey 2 & 15 & 3.51 \\
OFMSW leachate & 11 & 6.88 \\
\hline
\end{tabular}

could be underlined that, for all the substrates, except from slaughterhouse waste, the maximum production rate was performed within the first 24 hours of digestion, moreover, maximum specific methane flux in condensate water was higher than in OFMSW leachate and cheese whey.

In the work reported $\mathrm{in}^{34}$, BMP tests on OFMSW leachate were performed; waste-to-water ratio, in this case, was fixed at 1:8 (lower than the actual research, where this ratio was 1:2.1), and 67 $\%$ VS extraction was obtained after 4.5 days. In BMP curves, two separate peaks were observed, corresponding to two main stages: the first, from the starting of the tests until day 3, was identified with the conversion of easily biodegradable substances, while the second (from day 3 to day 10) corresponded to the degradation of slowly degradable molecules. Also in these tests, methane generation was interrupted just after 10-12 days of digestion, indicating that the BMP value was already reached: as a substrate characterized by good biodegradability, leachate does not require long digestion times to be completely degraded. 


\section{Continuous tests}

The results obtained from continuous tests on diluted whey are plotted in Fig. 4. It could be noticed that granular biomass successively adapted to this complex substrate; however, due to the extreme heterogeneity of whey, some variations were evident in $\mathrm{tCOD}_{\text {in }}\left(1.11 \pm 0.11 \mathrm{~g} \mathrm{~L}^{-1}\right)$.

Mean OLR was calculated as $0.88 \mathrm{~kg}$ COD m$~^{-3} \mathrm{~d}^{-1}$; tCOD removal progressively increased (mean value of $68.96 \%$ ), reaching final values greater than $80 \%$ (maximum $85.75 \%$ ). Moreover, it could be highlighted that, after a period of 16 days, $\mathrm{tCOD}_{\text {out }}$ was always below $200 \mathrm{mg} \mathrm{L}^{-1}$, indicating good stability of the system despite of the fluctuating influent characteristics. Mean methane production for the UASB reactor was 0.148 $\mathrm{Nm}^{3} \mathrm{CH}_{4} \mathrm{~kg}^{-1} \mathrm{COD}$.

A similar behaviour was observed with sCOD, where mean $\mathrm{SCOD}_{\text {in }}$ and $\mathrm{SCOD}_{\text {out }}$ were, respectively, $0.88 \pm 0.09 \mathrm{~g} \mathrm{~L}^{-1}$ and $0.26 \pm 0.06 \mathrm{~g} \mathrm{~L}^{-1}$.

As a comparison, in the work reported in ${ }^{33}$, diluted cheese whey was treated using a UASB reactor, and an excellent COD removal of 95-97\% was obtained. Moreover, a higher methane yield was achieved $\left(0.424 \mathrm{Nm}^{3} \mathrm{CH}_{4} \mathrm{~kg}^{-1} \mathrm{COD}\right)$, if compared to the present study, using a HRT of 2.1-2.5 days. Applied OLR was 22.6-24.6 g COD L ${ }^{-1} \mathrm{~d}^{-1}$ (significantly higher than that in this work), and biogas was characterized by high methane content $(77 \%)$.

From these basic results, it can be concluded that high-velocity anaerobic treatment of dairy products, and in particular of diluted cheese whey, is feasible, even if a detailed study is required to obtain more information about long-term methane yields and performance of the system.

As for P\&P wastewater, it has been proved that UASB is an effective technology to treat this substrate, and, in fact, in literature, a recent work ${ }^{35}$ highlights a $80-85 \%$ reduction in COD, with production of $0.52 \mathrm{~m}^{3}$ biogas $\mathrm{kg}^{-1} \mathrm{COD}$. $\mathrm{In}^{36}, 70-75 \%$ COD reduction and 85-90\% BOD removal were reported, coupled with a methane yield of $0.31-0.33$ $\mathrm{m}^{3} \mathrm{~kg}^{-1} \mathrm{COD}_{\text {reduced }}$. A successive phase of the work will be continuous tests extension to condensate wastewater, to deeply investigate UASB performances on this substrate, taking into account literature evidences.

\section{Conclusions}

Physicochemical characterization of selected substrates (condensate water, first and second cheese whey, OFMSW leachate, slaughterhouse liquid waste) highlighted wide differences among these liquid matrixes, and BMP tests revealed that they were somewhat suitable for anaerobic treatment.

Some assumptions useful for high-rate anaerobic digestion were made: OFMSW leachate, being a highly soluble substrate, produced high methane yields and demonstrated a high-rate methane production; cheese whey, having an extreme COD concentration, could easily lead to reactor acidification; condensate water, as a highly acidic substrate, revealed relatively low methane production, and slaughterhouse waste was digested at the slowest rate, because of its high solids content.

A lab-scale UASB reactor, treating diluted cheese whey, was installed and start-up was performed, with interesting COD reduction.

\section{ACKNOWLEDGMENTS}

This work was supported by Friuli-Venezia Giulia region (PAR FSC 2007-2013- LR 47/78, Action line 3.1.1, "UASB pre-treatment to optimize energy recovery and smell nuisance reduction", grant number 0797). The authors would like to thank Carniacque and CAFC S.p.A. companies for technical and financial support.

The authors also acknowledge Friuli-Venezia Giulia facilities, namely Artelatte (Ovaro, Ud) and Val Tagliamento (Enemonzo, Ud) cheese factories and Larice (Amaro, Ud) slaughterhouse.

\section{References}

1. Mata-Alvarez, J., Dosta, J., Romero-Guiza, M. S., Fonoll, X., Peces, M., Astals, S., A critical review on anaerobic co-digestion achievements between 2010 and 2013, Renew. Sustain. Energy Rev. 36 (2014) 412. doi: https://doi.org/10.1016/j.rser.2014.04.039

2. Khalid, A., Arshad, M., Anjum, M., Mahmood, T., Dawson, $L$., The anaerobic digestion of solid organic waste, Waste Manag. 31 (2011) 1737.

doi: https://doi.org/10.1016/j.wasman.2011.03.021

3. Escalante, H., Castro, L., Gauthier-Maradei, P., De La $V e g a, R$. R., Spatial decision support system to evaluate crop residue energy potential by anaerobic digestion, Bioresour. Technol. 219 (2016) 80. doi: https://doi.org/10.1016/j.biortech.2016.06.136

4. Lim, S. J., Kim, T.-H., Applicability and trends of anaerobic granular sludge treatment process, Biomass Bioenergy 60 (2014) 189.

doi: https://doi.org/10.1016/j.biombioe.2013.11.011

5. Chen, Y., Cheng, J. J., Creamer, K. S., Inhibition of anaerobic digestion process: A review, Bioresour. Technol. 99 (2008) 4044.

doi: https://doi.org/10.1016/j.biortech.2007.01.057

6. Carvalho, F., Prazeres, A. R., Rivas, J., Cheese whey wastewater: Characterization and treatment, Sci. Total Environ. 445-446 (2013) 385.

doi: https://doi.org/10.1016/j.scitotenv.2012.12.038 
7. Prazeres, A. R., Carvalho, F., Rivas, J., Cheese whey management: A review, J. Environ. Manag. 110 (2012) 48. doi: https://doi.org/10.1016/j.jenvman.2012.05.018

8. Andrade, L. H., Mendes, F. D. S., Espindola, J. C., Amaral, M. C. S., Nanofiltration as tertiary treatment for the reuse of dairy wastewater treated by membrane bioreactor, Sep. Purif. Technol. 126 (2014) 21. doi: https://doi.org/10.1016/j.seppur.2014.01.056

9. Kalyuzhnyi, S. V., Perez Martinez, E., Rodriguez Martinez, $J$, Anaerobic treatment of high-strength cheese-whey wastewaters in laboratory and pilot UASB-reactors, Bioresour. Technol. 60 (1997) 59. doi: https://doi.org/10.1016/S0960-8524(96)00176-9

10. Browne, J. D., Allen, E., Murphy, J. D., Improving hydrolysis of food waste in a leach bed reactor, Waste Manag. 33 (2013) 2470.

doi: https://doi.org/10.1016/j.wasman.2013.06.025

11. Xu, S. Y., Lam, H. P., Kathikeyan, O. P., Wong, J. W. C., Optimization of food waste hydrolysis in leach bed coupled with methanogenic reactor: Effect of $\mathrm{pH}$ and bulking agent, Bioresour. Technol. 102 (2011) 3702. doi: https://doi.org/10.1016/j.biortech.2010.11.095

12. Florez-Juarez, C. R., Rodriguez-Garcia, A., Cardenas-Mijangos, J., Montoya-Herrera, L., Mora-Tovar, L. A. G., Bustos-Bustos, E., Rodriguez-Valadez, F., Manriquez Rocha, J., Chemically pretreating slaughterhouse solid waste to increase the efficiency of anaerobic digestion, J. Biosci. Bioeng. 118 (4) (2014) 415 doi: https://doi.org/10.1016/j.jbiosc.2014.03.013

13. Kafle, G. K., Chen, L., Comparison on batch anaerobic digestion of five different livestock manures and prediction of biochemical methane potential (BMP) using different statistical models, Waste manag. 48 (2016) 492. doi: https://doi.org/10.1016/j.wasman.2015.10.021

14. Raposo, F., De la Rubia, M. A., Fernández-Cegrí, V., Borja, $R$., Anaerobic digestion of solid organic substrates in batch mode: An overview relating to methane yields and experimental procedures, Renew. Sustain. Energy Rev. 16 (2011) 861 .

doi: https://doi.org/10.1016/j.rser.2011.09.008

15. Wu, J., Afridi, Z. U. R., Cao, Z. P., Zhang, Z. L., Poncin, S., Li, H. Z., Zuo, J. E., Wang, K. J., Size effect of anaerobic granular sludge on biogas production: A micro scale study, Bioresour. Technol. 202 (2016) 165.

doi: https://doi.org/10.1016/j.biortech.2015.12.006

16. Campuzano, R., Gonzalez-Martinez, S., Extraction of soluble substances from organic solid municipal waste to increase methane production, Bioresour. Technol. 178 (2015) 247.

doi: https://doi.org/10.1016/j.biortech.2014.08.042

17. Browne, J. D., Murphy, J. D., The impact of increasing organic loading in two phase digestion of food waste, Renew. Energy 71 (2014) 69. doi: https://doi.org/10.1016/j.renene.2014.05.026

18. Voelklein, M. A., Jacob, A., O'Shea, R., Murphy, J. D., Assessment of increasing loading rate on two-stage digestion of food waste, Bioresour. Technol. 202 (2016) 172. doi: https://doi.org/10.1016/j.biortech.2015.12.001

19. APHA, Standard methods for the Examination of Water and Wastewater, $21^{\text {st }}$ ed. American Public Health Association, America Water Works Association, Water Environment Federation, Washington DC (2005).

20. Dubois, M., Gilles, K. A., Hamilton, J. K., Rebers, P. A., Smith, $F$., Colorimetric method for determination of sugars and related substances, Anal. Chem. 28 (1956) 350. doi: https://doi.org/10.1021/ac60111a017
21. Cabbai, V., Ballico, M., Aneggi, E., Goi, D., BMP tests of source selected OFMSW to evaluate anaerobic codigestion with sewage sludge, Waste Manag. 33 (2013) 1626. doi: https://doi.org/10.1016/j.wasman.2013.03.020

22. Rouch, D. A., Roginski, H., Britz, M. L., Roupas, P., Determination of a nitrogen conversion factor for protein content in Cheddar cheese, Int. Dairy J. 18 (2008) 216. doi: https://doi.org/10.1016/j.idairyj.2007.07.004

23. Raposo, F., Fernandez-Cegri, V., De La Rubia, M. A., Borja, R., Beline, F., Cavinato, C., Demirer, G., Fernandez, B., Fernandez-Polanco, M., Frigon, J. C., Ganesh, R., Kaparaju, P., Koubova, J., Mendez, R., Menin, G., Peene, A., Scherer, P., Torrijos, M., Uellendahl, H., Wierinckm, I., De Wilde, $V$., Biochemical methane potential (BMP) of solid organic substrates: Evaluation of anaerobic biodegradability using data from an international interlaboratory study, J. Chem. Technol. Biotechnol. 8 (2011) 1088. doi: https://doi.org/10.1002/jctb.2622

24. Koch, K., Fernandez, Y. B., Drewes, J. E., Influence of headspace flushing on methane production in Biochemical Methane Potential (BMP) tests, Bioresour. Technol. 186 (2015) 173. doi: https://doi.org/10.1016/j.biortech.2015.03.071

25. Gomes, D. R. S., Papa, L. G., Cichello, G. C. V., Belançon, D., Pozzi, E. G., Balieiro, J. C. C, Monterrey-Quintero, E. $S$., Tommaso, G., Effect of enzymatic pretreatment and increasing the organic loading rate of lipid-rich wastewater treated in a hybrid UASB reactor, Desalin. 279 (2011) 96. doi: https://doi.org/10.1016/j.desal.2011.05.067

26. Ahmad, M. I., Ejaz, O., Ali, A., Durrani, M. A. Q. J., Khan, I. A., Anaerobic digestion of waste from a slaughterhouse, J. Environ. Chem. Eng. 2 (2014) 1317. doi: https://doi.org/10.1016/j.jece.2014.04.001

27. Abbasi, T., Abbasi, S. A., Formation and impact of granules in fostering clean energy production and wastewater treatment in upflow anaerobic sludge blanket (UASB) reactors, Renew. Sustain. Energy Rev. 16 (2012) 1696. doi: https://doi.org/10.1016/j.rser.2011.11.017

28. Singh, R. P., Kumar, S., Ojha, C. S. P., Nutrient requirement for UASB process: A review, Biochem. Eng. J. 3 (1999) 35 doi: https://doi.org/10.1016/S1369-703X(98)00043-6

29. Latif, M. A., Ghufran, R., Wahid, Z. A., Ahmad, A., Integrated application of upflow anaerobic sludge blanket reactor for the treatment of wastewaters, Water Res. 45 (2011) 4683 doi: https://doi.org/10.1016/j.watres.2011.05.049

30. Malina, J. F., Pohland, F. G., Design of anaerobic processes for the treatment of industrial and municipal wastes, Water Quality Management Library, Vol. 7, Lancaster, Pennsylvania, 1992.

31. Caixeta, C. E. T., Cammarota, M. C., Xavier, A. M. F., Slaughterhouse wastewater treatment: Evaluation of a new three-phase separation system in a UASB reactor, Bioresour. Technol. 81 (2002) 61. doi: https://doi.org/10.1016/S0960-8524(01)00070-0

32. Karadag, D., Koroglu, O. E., Ozkaya, B., Cakmakci, M., Heaven, S., Banks, C., Serna-Maza, A., Anaerobic granular reactors for the treatment of dairy wastewater: A review, Int. J. Dairy Technolog. 68 (4) (2015) 459. doi: https://doi.org/10.1111/1471-0307.12252

33. Erguder, T. H., Tezel, U., Guven, E., Demirer, G. N., Anaerobic biotransformation and methane generation potential of cheese whey in batch and UASB reactors, Waste Manag. 21 (2001) 643. doi: https://doi.org/10.1016/S0956-053X(00)00114-8

34. Bolzonella, D., Fatone, F., Pavan, P., Cecchi, F., Anaerobic fermentation of organic municipal solid wastes for the pro- 
duction of soluble organic compounds, Ind. Eng. Chem. Res. 44 (10) (2005) 3412.

doi: https://doi.org/10.1021/ie048937m

35. Chinnaraj, S. A., Rao, G. V., Implementation of an UASB anaerobic digester at bagasse-based pulp and paper industry, Biomass Bioenerg. 30 (2006) 273.

doi: https://doi.org/10.1016/j.biombioe.2005.10.007
36. Rao, A. G., Bapat, A. N., Anaerobic treatment of pre-hydrolysate liquor (PHL) from a rayon grade pulp mill: Pilot and full-scale experience with UASB reactors, Bioresour. Technol. 97 (2006) 2311.

doi: https://doi.org/10.1016/j.biortech.2005.10.033 